See discussions, stats, and author profiles for this publication at: https://www.researchgate.net/publication/316710089

Response to: “Are muscle weakness and falls status really correlated in physically active women? A comment to Crozara et al. (2016)'

Article in Isokinetics and exercise science · April 2017

DOI: 10.3233/IES-179130

\section{CITATIONS}

0

8 authors, including:

A Luciano Fernandes Crozara

2. Faculdade de Medicina de Marília

32 PUBLICATIONS 95 CITATIONS

SEE PROFILE

(A) Nise R Marques

São Paulo State University

63 PUBliCATIONS 258 CITATIONS

SEE PROFILE
READS

58

Mary Hellen Morcelli

33 PUBLICATIONS 139 CITATIONS

SEE PROFILE

Deborah Hebling

São Paulo State University

24 PUBlications 47 CITATIONS

SEE PROFILE

Some of the authors of this publication are also working on these related projects:

Minority Health View project

Análise de parâmetros neuromusculares e cinemáticos dos chutes Bandal Chagui e Dolho Chagui do Taekwondo View project 
IOS Press

\title{
Response to: "Are muscle weakness and falls status really correlated in physically active women? A comment to Crozara et al. (2016)"
}

\author{
Luciano F. Crozara ${ }^{\mathrm{a}, *}$, Mary H. Morcelli ${ }^{\mathrm{b}}$, Camilla Z. Hallal ${ }^{\mathrm{c}}$, Nise R. Marques ${ }^{\mathrm{b}}$, Deborah H. Spinoso ${ }^{\mathrm{b}}$, \\ Márcio F. Goethel $^{\mathrm{d}}$, Edgar R. Vieira ${ }^{\mathrm{e}}$ and Mauro Gonçalves ${ }^{\mathrm{f}}$ \\ ${ }^{a}$ Lucy Montoro Rehabilitation Center, Marília College of Medicine, Marília, São Paulo, Brazil \\ ${ }^{\mathrm{b}}$ Department of Physical Therapy and Occupational Therapy, São Paulo State University, Marília, São Paulo, \\ Brazil \\ ${ }^{\mathrm{c}}$ Faculty of Physical Education and Physical Therapy, Federal University of Uberlândia, Uberlândia, Minas \\ Gerais, Brazil \\ ${ }^{\mathrm{d}}$ Department of Research and Development Spine Implants Import \& Export Ltd. Rio Claro, São Paulo, Brazil \\ ${ }^{\mathrm{e}}$ Department of Physical Therapy, Nicole Wertheim College of Nursing \& Health Sciences, Florida International \\ University, Miami, FL, USA \\ ${ }^{\mathrm{f}}$ Laboratory of Biomechanics, Department of Physical Education, São Paulo State University, Rio Claro, São \\ Paulo, Brazil
}

In our recent article [1] we found lower-extremity muscle activation and joint torque and power to be associated with falls in physically active older women. Our results showed that knee flexion-extension torque and power, ankle dorsiflexion power and rectus femoris activity during $90^{\circ} \mathrm{s}$ movements were able to differentiate between younger and older women and were associated with falls in older women. In their letter to editor, Cattagni and colleagues raised the possibility that cognitive and balance impairments could have confounded our findings. We appreciate Cattagni and colleagues' interest in our work and the opportunity to discuss this important issue.

We agree that potential confounding variables should be controlled for. In our study, we assessed

\footnotetext{
${ }^{*}$ Corresponding author: Luciano F. Crozara, Faculdade de Medicina de Marília Centro de Reabilitação Lucy Montoro, Av. Nelsom Severino Zambon, 175, Fragata, Marília-SP 17519-110 Brazil. Tel. +55 143402 1700; E-mail: lucianoeduca@gmail.com.
}

cognitive status using the Mini Mental State Examination (MMSE) and evaluated balance using the Berg Balance Scale (BBS). The difference between fallers and non-fallers on MMSE (mean difference = 2 ) and BBS scores (mean difference $=1$ ) were not clinically important even though statistically significant, and the mean scores classified the participants in both groups (fallers and non-fallers) as cognitively preserved [2] and having near-excellent functional balance [3]. Therefore, the findings cannot be attributable to cognitive and balance impairments in older women with fall history.

Cattagni and colleagues also proposed some methodological considerations on the absence of significant differences between young and older adults on ankle muscles co-contraction. The differences between our results and those from earlier studies [4-6] can be explained by the different assessments used. In our study we did isokinetic evaluations while the previous studies mentioned used isometric evaluations. In ad- 
dition, the differences may be related to the methodological approaches used to calculate the levels of cocontraction $[7,8]$. We used the method proposed by Winter [9] because it better represents the movement analyzed (i.e. pooled ankle plantarflexion and dorsiflexion) and it approximates real world conditions because knee and ankle agonist and antagonist muscle contraction characteristics change during functional tasks (e.g. walking). Co-contraction level estimates are related to the ability to control and coordinate joint movements $[8,9]$. The co-contraction level in the study cited by Cattagni and colleagues [4] was calculated using the ratio between the EMG activity of a muscle when acting as an antagonist and the EMG activity of the same muscle when acting maximally as an agonist. This ratio could be misleading because it does not include the agonist of the task of interest in the cocontraction calculation [7]. With respect to the lowerextremity muscles analyzed, we assessed only the rectus femoris, vastus lateralis, biceps femoris, tibialis anterior and lateral gastrocnemius because we had no additional EMG channels left to use with our current electromyographer. However, we agree with Cattagni and colleagues that an investigation of all triceps surae muscles could provide more complete information of potential disturbances on the ankle co-contraction level with aging. Thank you again, for contributing to the discussion and interpretation of our findings.

\section{References}

[1] Crozara LF, Morcelli MH, Hallal CZ, Marques NR, Spinoso $\mathrm{DH}$, Goethel MF, et al. Effect of age and fall status on lowerextremity muscle activation and joint torque and power in physically active women. Isokinetic Exerc Sci. 2016; 24(1): 67-77. doi: 10.3233/IES-150602.

[2] Brucki SM, Nitrini R, Caramelli P, Bertolucci PH, Okamoto IH. Suggestions for utilization of the mini-mental state examination in Brazil Arq Neuropsiquiatr. 2003; 61(3B): 777-781.

[3] Shumway-Cook A, Brauer S, Woollacott M. Predicting the probability for falls in community-dwelling older adults using the Timed Up \& Go Test. Phys Ther. 2000; 80(9): 896-903.

[4] Simoneau EM, Billot M, Martin A, Van Hoecke J. Antagonist mechanical contribution to resultant maximal torque at the ankle joint in young and older men. J Electromyogr Kinesiol. 2009; 19(2): e123-131. doi: 10.1016/j.jelekin.2007.11.006.

[5] Billot M, Simoneau EM, Van Hoecke J, Martin A. Age-related relative increases in electromyography activity and torque according to the maximal capacity during upright standing. Eur J Appl Physiol. 2010; 109(4): 669-680. doi: 10.1007/s00421010-1397-7.

[6] Cattagni T, Scaglioni G, Laroche D, Gremeaux V, Martin A. The involvement of ankle muscles in maintaining balance in the upright posture is higher in elderly fallers. Exp Gerontol. 2016; 77: 38-45. doi: 10.1016/j.exger.2016.02.010.

[7] Clark DJ, Fielding RA. Neuromuscular contributions to agerelated weakness. J Gerontol A Biol Sci Med Sci. 2012; 67(1): 41-47. doi: 10.1093/gerona/glr041.

[8] Izquierdo M, Ibañez J, Gorostiaga E, Garrues M, Zúñiga A, Antón A, et al. Maximal strength and power characteristics in isometric and dynamic actions of the upper and lower extremities in middle-aged and older men. Acta Physiol Scand. 1999; 167(1): 57-68. doi: 10.1046/j.1365-201x.1999.00590.x.

[9] Winter AD. Biomechanics and motor control of human movement. Waterloo: Wiley-Interscience Publication; 1990. 